\title{
Bacteria transport and retention in intact calcareous soil columns under saturated flow conditions
}

\author{
Ahmad Farrokhian Firouzi ${ }^{1}$, Mehdi Homaee ${ }^{1 *}$, Erwin Klumpp ${ }^{2}$, Roy Kasteel ${ }^{2}$, Wolfgang Tappe ${ }^{2}$ \\ ${ }^{1}$ Department of Soil Science, Tarbiat Modares University, Jalal Ale Ahmad Highway, Tehran 14155-336, Iran. \\ ${ }^{2}$ Agrosphere Institute, IBG-3, Forschungszentrum Jülich GmbH, Wilhelm-Johnen Str., 52428 Jülich, Germany. \\ ${ }^{*}$ Corresponding author. Tel.: +982166026522. Fax:+982166026524. E-mail: mhomaee@modares.ac.ir
}

\begin{abstract}
Study of bacterial transport and retention in soil is important for various environmental applications such as groundwater contamination and bioremediation of soil and water. The main objective of this research was to quantitatively assess bacterial transport and deposition under saturated conditions in calcareous soil. A series of leaching experiments was conducted on two undisturbed soil columns. Breakthrough curves of Pseudomonas fluorescens and $\mathrm{Cl}$ were measured. After the leaching experiment, spatial distribution of bacteria retention in the soil columns was determined. The HYDRUS-1D one- and two-site kinetic models were used to predict the transport and deposition of bacteria in soil. The results indicated that the two-site model fits the observed data better than one-site kinetic model. Bacteria interaction with the soil of kinetic site 1 revealed relatively fast attachment and slow detachment, whereas attachment to and detachment of bacteria from kinetic site 2 was fast. Fast attachment and slow detachment of site 1 can be attributed to soil calcium carbonate that has favorable attachment sites for bacteria. The detachment rate was less than 0.02 of the attachment rate, indicating irreversible attachment of bacteria. High reduction rate of bacteria was also attributed to soil calcium carbonate.
\end{abstract}

Keywords: Bacteria transport; Calcareous soil; Pseudomonas fluorescens; Saturated flow.

\section{INTRODUCTION}

Bacteria transport and retention in soil is important for processes ranging from contaminant degradation during in situ bioremediation to transport of pathogen bacteria to groundwater. Soil is traditionally considered as an effective bacterial filter (Gilbert et al., 1976; Guber et al., 2005; Kadam et al., 2008; Pachepsky et al., 2006; Stevik et al., 2004). But, soils usually contain some macropores that work as pathways of rapid transport of bacteria. Soil macropores can significantly increase the transport of bacteria. Smith et al. (1985) concluded that the transport of bacteria through sieved or mixed soil columns will be negligible compared to more structured soils. van Elsas et al. (1991) found that Pseudomonas fluorescens bacteria are transported to lower soil layers to a significantly higher degree in undisturbed soil columns than in repacked columns. Several studies (e.g. Cey et al., 2009; Darnault et al., 2004; Guber et al., 2005; Jiang et al., 2010; Pang et al., 2008; Pivetz et al., 1996; Unc and Goss, 2003; Wang et al., 2013) have revealed that microorganisms and colloids can transport within preferential flow pathways.

Several mechanisms are responsible to control the transport of bacteria in saturated soil. These are (i) transport (advection and dispersion) (ii) exchange between the liquid phase and the solid phase (attachment and detachment) (iii) inactivation (dieoff), and (iv) straining (Gargiulo et al., 2008; Tufenkji, 2007). The inactivation or die-off of bacteria in the liquid phase and bacteria attached to the soil are influenced by many factor such as temperature, light, $\mathrm{pH}$, toxic substances, oxygen, protozoa and antagonist. Straining is the trapping of particles in downgradient pore throats that are too small to allow the particles to pass through (Foppen et al., 2007).

Several studies have investigated the transport and deposition of bacteria under saturated condition (Foppen and Schijven, 2006; Foppen et al., 2010; Hagedorn et al., 1978; Hendry et al.,
1999; McCaulou et al., 1995; Syngouna and Chrysikopoulos, 2011; Tufenkji and Elimelech, 2004). However, most of them have used columns packed with artificial soil and aquifer materials and only few works have been conducted on modeling bacterial transport in intact natural soil. Bacterial transport in soil is also affected by soil composition. Soil minerals, one of the most important components of soil, play a major role on bacteria transport. Flynn et al. (2004) showed that calcite retained bacteriophages much greater than quartz or feldspar. Calcite at neutral $\mathrm{pH}$ has effective positive attachment sites for negatively charged colloids.

Foppen and Schijven (2005) concluded that mineralogy is an important factor which influences $E$. coli retention. Their results demonstrated that in quartz sand coated with calcite in varying fractions $(0,5 \%, 10 \%, 20 \%, 40 \%, 70 \%$, and $100 \%)$, the sticking efficiencies of $E$. coli increases with increasing the fraction of quartz sand coated with calcite. Pang et al. (2008) studied transport of fecal coliforms, Salmonella bacteriophage, and $\mathrm{Br}$ in undisturbed lysimeters soils. The results indicated that soil structure plays the most important function in the transport of microbes and $\mathrm{Br}$, while soil lithology had the greatest influence on mass exchange.

Attachment of bacteria to soil may be modeled as either irreversible (no detachment) or reversible. Schijven et al. (2002) classified two types of reversible attachment, equilibrium and kinetic. Attachment at kinetic sites is usually assumed to exhibit a time-dependent, first-order reversible reaction; while sorption at equilibrium sites is assumed to be instantaneous and can be represented using either linear or nonlinear adsorption isotherms. Research suggests that the equilibrium sorption mechanism is not appropriate for describing microbial attachment under most conditions (Tufenkji, 2007). Agricultural soils are chemically heterogeneous porous media composed of different minerals with favorable (e.g. $\mathrm{CaCO}_{3}$ ) and unfavorable attachment sites for attachment of negatively charged bacteria. Thus, 
presence of more than one kinetic attachment site in natural soils should be considered.

In developing countries the main source of drinking water is groundwater (Foppen and Schijven, 2006; Foster, 2000). The results of several investigations have shown bacterial transport from a few meters to $83 \mathrm{~m}$ depending on soil permeability, water saturation degree, and length of time (Hagedorn et al., 1978; McMurry et al., 1998). Therefore, quantitative assessment of microbial transport in different soil types would help to evaluate the risk of groundwater contamination. Consequently, the main objectives of this study were to quantitatively investigate the bacterial transport and retention under saturated conditions in calcareous soil and to evaluate the one- and two-site kinetic models to predict bacteria transport.

\section{MATERIALS AND METHODS Bacteria}

The bacterial strain Pseudomonas fluorescens (DSM 50108 Biotype II) in the stationary growth phase was used in the column leaching experiments. This bacterium is motile, normally rod-shaped and gram-negative. The bacterial strain was cultivated at $25^{\circ} \mathrm{C}$ in a nutrient broth that was agitated at $130 \mathrm{rpm}$ using a shaker. The bacteria cells were harvested from the nutrient broth in the late stationary phase by gentle centrifugation $\left(10 \mathrm{~min}, 8000 \mathrm{rpm}, 25^{\circ} \mathrm{C}\right)$ and re-suspended in $0.01 \mathrm{M} \mathrm{CaCl}_{2}$. The bacteria concentration in the influent suspension was determined using a coulter counter (BECKMAN COULTER Multisizer 3). The bacteria concentration in the effluent samples was determined using fluorescence microscopy techniques (Klauth et al., 2004). To determine the bacteria retention profile, the experimental column was cut in 10 slices. A 10 -g soil sample and $40-\mathrm{mL} \mathrm{CaCl}_{2} 0.01 \mathrm{M}$ were added into centrifuge tube, which were shaken for 15 minutes in a horizontal shaker at 200 $\mathrm{rpm}$. The soil suspension was then centrifuged at $1400 \times \mathrm{g}$ during $3 \mathrm{~min}$, and $P$. fluorescens content was determined in the supernatant. Cell concentration in the supernatant was determined by serial dilution and plate counting in $\mathrm{S}$ medium (Gould et al., 1985).

\section{Transport experiment}

Two undisturbed calcareous soil (Calcixerollic Xerochrepts) columns were collected from the upper $30 \mathrm{~cm}$ of an agricultural field in Lorestan Province, Iran ( $\left.48^{\circ} 14^{\prime} \mathrm{E}, 33^{\circ} 49^{\prime} \mathrm{N}\right)$. The PVC constructed columns with inner diameter of $8 \mathrm{~cm}$ and heights of $10 \mathrm{~cm}$ were used for all experiments. The method of Mosaddeghi et al. (2009) was used for soil sampling. The internal walls of the columns were lubricated with liquid paraffin before sampling, in order to avoid soil disturbance during sampling. The soil was deeply watered and the columns were pushed into the soil using a wooden hammer. The columns were carefully excavated afterwards.

All soil column experiments were run with software-controlled equipment. The setup was controlled with a Lab View based software. Before starting the displacement experiment, the soil columns were subjected to capillary saturation from the bottom with $0.01 \mathrm{M} \mathrm{CaCl}_{2}$ for two consecutive days. In order to establish steady state flow conditions, the soil columns were irrigated with a $0.01 \mathrm{M} \mathrm{CaCl}_{2}$ solution at a constant rate using an irrigation device with 12 needles. The device was placed on the top of the columns. The influent solution was supplied by a flexible-tube pump and the irrigation rate was controlled by weighing the water loss from the fluent storage.

Transport experiments were conducted in two soil columns denoted as I and II (Table 1). Bacteria suspension was applied to the top of columns, and a head of suspension less than $0.5 \mathrm{~cm}$ was kept above the soil surface. Pulse durations for column I and II under saturated condition were 8 and 7 hours, respectively. Prior to bacteria transport experiments, chloride was used as a non-reactive tracer to characterize water flow and solute transport pathways of the soil columns. The chloride concentration in the outflow samples was measured using an electrical conductivity sensor (Cond 340i, WTW GmbH, Weilheim, Germany). The outflow was collected in test tubes by a fraction collector. For measuring the chloride breakthrough curves (BTCs), the $0.01 \mathrm{M} \mathrm{CaCl}_{2}$ solution was replaced by a $0.05 \mathrm{M}$ $\mathrm{CaCl}_{2}$ solution. For determining the bacteria-BTCs, the $0.01 \mathrm{M}$ $\mathrm{CaCl}_{2}$ solution was replaced by the bacteria suspension. When the transport experiments were finished, the soil columns were cut into slices of $1 \mathrm{~cm}$ thickness, in order to detect the bacterial retention in the soil column profile.

Bacteria and chloride breakthrough data was expressed in terms of the relative concentration, that is, the concentration in the effluent $C$ divided by initial concentration at time $\mathrm{t}=0 C_{0}$ vs. the pore volumes.

Particle-size distribution was determined using hydrometer method, organic carbon (OC) by wet oxidation with chromic acid and back titration with ferrous ammonium sulphate (Nelson, 1982). Soil $\mathrm{pH}$ was measured in a saturation paste, active calcium carbonate equivalent (ACCE) by the ammonium oxalate method (Drouinean, 1942) and electrical conductivity in the saturation extract (ECe) by a conductivity meter. Some physical and chemical properties of the experimental soil columns are given in Table 1. The soil has clay loam texture. The amounts of active calcium carbonate contents were 26.3 and $31.50 \%$ for soil columns I and II, respectively.

\section{Theory and model \\ Solute transport}

Solute transport is described using the advection-dispersion equation (ADE), which for non-reactive tracers under steady state flow conditions can be written as:

$$
\frac{\partial C}{\partial t}=-v \frac{\partial C}{\partial z}+D \frac{\partial^{2} C}{\partial z^{2}}
$$

where $C$ is the solute concentration in the liquid phase $\left[\mathrm{M} \mathrm{L}^{-3}\right], t$ is time $[\mathrm{T}], v$ is the average pore-water velocity $\left[\mathrm{L} \mathrm{T}^{-1}\right], D$ is the dispersion coefficient $\left[\mathrm{L}^{2} \mathrm{~T}^{-1}\right]$, and $z$ is depth [L].

The parameters $v$ and $D$ for the chloride BTCs were estimated using a non-linear parameter estimation procedure based on the Levenberg-Marquardt algorithm. The CXTFIT code

Table 1. Some physical and chemical properties of the experimental soil columns.

\begin{tabular}{lccccccc}
\hline Soil column & $\begin{array}{c}\text { Clay } \\
(\%)\end{array}$ & $\begin{array}{c}\text { Silt } \\
(\%)\end{array}$ & $\begin{array}{c}\text { Bulk density } \\
\left(\mathrm{g} \mathrm{cm}^{-3}\right)\end{array}$ & $\mathrm{pH}$ & $\begin{array}{c}\mathrm{EC} \\
\left(\mathrm{dS} \mathrm{m}^{-1}\right)\end{array}$ & $\begin{array}{c}\text { OC } \\
(\%)\end{array}$ & $\begin{array}{c}\text { ACCE } \\
(\%)\end{array}$ \\
\hline I & 38 & 32.5 & 1.28 & 7.52 & 1.25 & 1.45 & 26.30 \\
II & 36.5 & 34.7 & 1.24 & 7.40 & 1.18 & 1.56 & 31.50 \\
\hline
\end{tabular}


(Toride et al., 1999) analytically solves the ADE for the appropriate boundary conditions. The estimated transport parameters $(v$ and $D)$ and the experimentally determined Darcian flux, $q\left[\mathrm{~L} \mathrm{~T}^{-1}\right]$, were then used to calculate the volumetric water content, $\theta=q / v\left[\mathrm{~L}^{3} \mathrm{~L}^{-3}\right]$, and the longitudinal dispersivity, $\lambda=$ $D / v[\mathrm{~L}]$.

\section{Bacteria transport}

The bacteria transport was modeled using a modified form of the advection-dispersion equation that includes two-site kinetic attachment-detachment model (Schijven et al., 2002). The total bacteria mass balance equation is defined as:

$$
\frac{\partial C}{\partial t}+\frac{\rho}{\theta} \frac{\partial S_{1}}{\partial t}+\frac{\rho}{\theta} \frac{\partial S_{2}}{\partial t}=D \frac{\partial^{2} C}{\partial z^{2}}-v \frac{\partial C}{\partial z}-\mu_{1} C
$$

where $S_{1}\left[\mathrm{~N}_{\mathrm{c}} \mathrm{m}^{-1}\right]$ and $S_{2}\left[\mathrm{~N}_{\mathrm{c}} \mathrm{m}^{-1}\right]$ are the solid phase concentrations associated with deposition sites 1 and 2 , respectively.

$$
\begin{aligned}
& \frac{\rho}{\theta} \frac{\partial S_{1}}{\partial t}=k_{\mathrm{att} 1} C-k_{\mathrm{det} 1} S_{1} \frac{\rho}{\theta}-\mu_{\mathrm{S}} \rho S_{1} \\
& \frac{\rho}{\theta} \frac{\partial S_{2}}{\partial t}=k_{\mathrm{att} 2} C-k_{\mathrm{det} 2} S_{2} \frac{\rho}{\theta}-\mu_{\mathrm{S}} \rho S_{2}
\end{aligned}
$$

where $\theta$ is the volumetric water content, $\rho$ is the soil bulk density $\left[\mathrm{M} \mathrm{L}^{-3}\right], C$ is the bacteria concentration in the liquid phase $\left[\mathrm{N}_{\mathrm{c}} \mathrm{L}^{-3}\right] \cdot k_{\text {att }}$ is the first-order attachment coefficient $\left[\mathrm{T}^{-1}\right], k_{\mathrm{det}}$ is the first-order detachment coefficient $\left[\mathrm{T}^{-1}\right]$. Subscripts 1 and 2 refer to the two different kinetic sites. The equation of one-site kinetic model is as same as equation (2) but, the parameter values for site 2 were set to zero. $\mu_{l}\left[\mathrm{~T}^{-1}\right]$ and $\mu_{s}\left[\mathrm{~T}^{-1}\right]$ represent inactivation and degradation processes in the liquid and solid phases.

The HYDRUS-1D one-site and two-site kinetic attachmentdetachment models were used to evaluate the transport and deposition of bacteria in soil columns. The code allows fitting model parameters to the breakthrough curve and the retention profile simultaneously, using a nonlinear least square optimization (Simunek et al., 2008). The two-site model assumes that the attachment sites on the solid phase can be divided into two fractions with different properties and various attachment and detachment rate coefficients. Both BTC and concentration profiles were used in the objective function. In order to obtain ade- quate fits for all BTCs during the simultaneous fitting process, the data points of bacteria and the concentration profile were weighted according to $C / C_{0}$ and $N_{\mathrm{t}} / \mathrm{N}_{\mathrm{i}}$, respectively. The $C / C_{0}$ reflects the relative effluent concentration, in which $C_{0}$ is the influent concentration of bacteria. The $N_{\mathrm{t}} / \mathrm{N}_{\mathrm{i}}$ denotes the number of bacteria found in each gram of soil $\left(\mathrm{N}_{\mathrm{t}}\right)$ divided by the total number of injected bacteria $\left(\mathrm{N}_{\mathrm{i}}\right)$.

The kinetic models were evaluated for the goodness of fit with modeling efficiency statistics $(E)$, (Nash and Sutcliffe, 1970).

$$
\begin{aligned}
& E=1-\frac{\sum_{i}^{n}\left(C_{\mathrm{obs}(\mathrm{i})}-C_{\mathrm{p}(\mathrm{i})}\right)^{2}}{\sum_{i}^{n}\left(C_{\mathrm{obs}(\mathrm{i})}-C_{\mathrm{avg}}\right)^{2}} \\
& C_{\mathrm{avg}}=\sum_{i}^{n} \frac{C_{\mathrm{obs}(\mathrm{i})}}{n}
\end{aligned}
$$

where $C_{\mathrm{p}(\mathrm{i})}$ and $C_{\mathrm{obs}(\mathrm{i})}$ are model predictions and observations effluent bacteria concentrations or bacteria retained in soil, respectively, $C_{\text {avg }}$ is the average of the observed effluent bacteria concentrations or bacteria retained in soil, and $n$ is the number of observations.

\section{RESULTS AND DISCUSSION \\ Transport of conservative solute}

The measured BTCs of chloride and the model fits with the ADE are demonstrated in Fig. 1. The estimated transport parameters using the CXTFIT program for the soil columns are given in Table 2. Model fits were excellent with $R^{2}$ values of 0.99 . The large estimated dispersivity can be attributed to flow and transport through macropores, which are activated under saturated conditions. Also, in undisturbed fine-textured soil, the pores in the soil matrix or intra-aggregate pores are small. When the leaching rate exceeds the conductivity of the intra-aggregate pores, there are activated leading to an increase of the dispersivity with increasing flow rate (Vanderborght and Vereecken, 2007).

The breakthrough curves are asymmetrical in shape (asymmetrical with respect to the $\mathrm{C} / \mathrm{C}_{0}=0.5$ point on the BTCs). The relative concentration $\mathrm{C} / \mathrm{C}_{0}$ in the effluent is obtained before one pore volume of chloride passed through the soil column. This phenomenon is known as early breakthrough. Furthermore, long
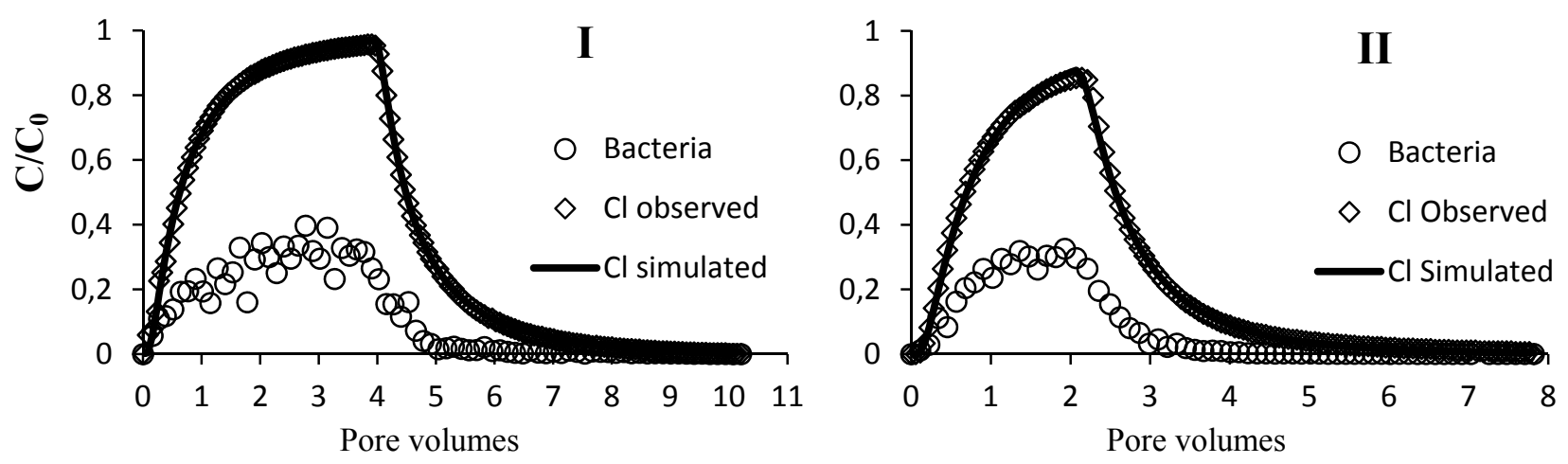

Fig. 1. Comparison of observed concentrations of $P$. fluorescens and chloride in the leachate of soil columns. The solid lines are predicted chloride BTC using CXTFIT model. I and II are the columns numbers. 

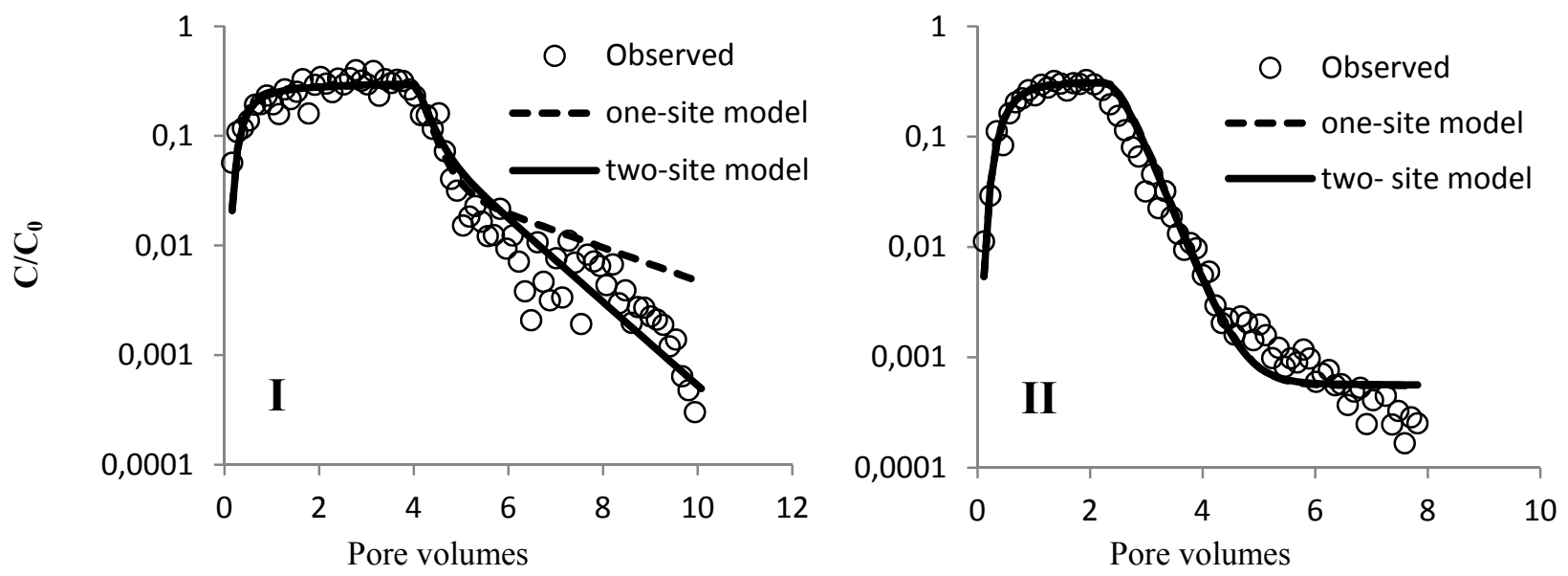

Fig. 2. Measured and fitted breakthrough curves for Pseudomonas fluorescens. I and II are the columns numbers.

Table 2. Transport parameters for the conservative tracer chloride.

\begin{tabular}{lcccccc}
\hline Soil column & $v\left(\mathrm{~cm} \mathrm{~h}^{-1}\right)$ & $D\left(\mathrm{~cm}^{2} \mathrm{~h}^{-1}\right)$ & $q\left(\mathrm{~cm} \mathrm{~h}^{-1}\right)$ & $\boldsymbol{\theta}\left(\mathrm{cm}^{3} \mathrm{~cm}^{-3}\right)$ & $\lambda(\mathrm{cm})$ & $R^{2}$ \\
\hline I & 5.96 & 36.30 & 2.58 & 0.44 & 6.09 & 0.99 \\
II & 4.73 & 22.90 & 2.31 & 0.48 & 4.84 & 0.99 \\
\hline
\end{tabular}

tailing of the BTCs is observed for the two experiments. The early breakthrough of chloride and long tails of the BTCs reveal the existence of preferential flow, suggesting that a portion of chloride moves through soil macropores.

\section{Transport of Bacteria \\ Breakthrough curves}

The measured BTCs of bacteria and chloride are presented in Fig. 1. Comparing the BTCs of bacteria and conservative tracer chloride indicate that bacteria occurred earlier than for chloride, which may be attributed to the exclusion of bacteria from smaller pores and the effect of macropores. Bacteria can only access a smaller range of larger pores due to size exclusion, whereas the chloride can access a wider range of pore sizes. Some other investigators have also observed an earlier breakthrough of bacteria than chloride in intact soils (Guber et al., 2005; Levy et al., 2007; Pang et al., 2008).

The observed and fitted breakthrough curves of bacteria are presented in Fig. 2. In this figure, the semi-log relative effluent concentration, $\log \left(C / C_{0}\right)$, where $C_{0}$ is the initial concentration of bacteria, is plotted against the pore volumes. The semi-log plots of breakthrough curves of bacteria have skewness. The BTCs are characterized by a rapid rising limb then followed by a smooth increase and a long tail. Similarly shaped breakthrough curves have been also reported for bacteria by some investigators (e.g. Johnson et al., 1995; McCaulou et al., 1994). The skewness of the rising and declining limbs is influenced by the value of $k_{\text {det2 }}$. The detachment of site 2 is high. Consequently, after a pulse of bacteria passed through soil, the influence of this site on the shape of BTCs would decrease. The tail of the breakthrough curve is determined by the values of $k_{\text {det } 1}$ and $\mu_{\mathrm{s}}$. Because bacteria detachment from this site is slow.

Table 3 gives a summary of the fitted one-site and two-site kinetic attachment-detachment models parameters. The detachment rate of bacteria in site one was less than 0.02 of the attachment rate. High attachment and low detachment rates of bacteria can be attributed to soil calcium carbonate. This result indicates that calcium carbonate can be almost a favorable irreversible attachment site. The $\mathrm{pH}_{\mathrm{PZC}}$ of $\mathrm{CaCO}_{3}$ ranges between 9.5 and 10.8 (Somasundaran and Agar, 1967). Because these $\mathrm{pH}_{\mathrm{PZC}}$ values are higher than that of the soil $\mathrm{pH}(7.40$ 7.52), the mineral has positively charged, and thus has high potential to attachment of negative charge of bacteria. Furthermore, presence of the divalent cation $\left(\mathrm{Ca}^{2+}\right)$ in the solution phase also reduces the electrostatic repulsion between negatively charged bacteria and soil particles.

The results further showed that bacteria interaction with kinetic site 1 had relatively fast attachment and slow detachment, whereas attachment to and detachment from kinetic site 2 was fast. Fast attachment and slow detachment of site 1 can also be attributed to soil calcium carbonate which has favorable attachment sites for bacteria.

The one-site model could not fully describe the tail of the measured breakthrough curve of column I. Whereas the two-site model, fitted the breakthrough curves reasonably well (Fig. 2). An improved prediction was obtained, using the two-site model (Table 4). The $E$ values of two-site for BTCs ranged from 0.92 to 0.95 . The results of Schijven et al., (2002) also showed that the two-site kinetic model compares to one-site kinetic attachment-detachment model provide a better description of bacteriophage breakthrough curves.

The standard error coefficient indicates the precision of estimated parameters (Table 3). Smaller values represent more reliable estimates. The standard error coefficient of all estimated parameters were small $\left(1.22 \times 10^{-7}\right.$ to $\left.5.79 \times 10^{-2}\right)$ except $k_{\text {att1 }}$ $\left(1.03 \times 10^{-1}\right), k_{\text {att2 }}\left(1.36 \times 10^{-1}\right)$ and $k_{\text {det2 }}\left(3.67 \times 10^{-1}\right)$ of two-site model in the soil column I.

\section{The effect of flow velocity on bacteria transport}

Breakthrough masses of bacteria were increased by increasing flow velocities. Bacteria retention in soil column I with low flow velocity was larger than that of column II with higher velocity (Table 5). This result can be explained by substantially larger time that bacteria have had to attach to soil particle surfaces. Also by increasing water flow velocity, the bacteria detachment process was facilitated by hydrodynamic shearing force. The detachment rate of bacteria in columns I and II were $3.22 \times 10^{-2}\left(\mathrm{~h}^{-1}\right)$ and $4.68 \times 10^{-4}\left(\mathrm{~h}^{-1}\right)$, respectively (Table 3 ). 
Table 3. Fitting parameters for the BTCs of bacteria (standard error coefficient).

\begin{tabular}{|c|c|c|c|c|}
\hline \multirow[t]{2}{*}{ Parameter } & \multicolumn{2}{|c|}{ Column I } & \multicolumn{2}{|c|}{ Column II } \\
\hline & One-site model & Two-site model & One-site model & Two-site model \\
\hline \multirow[t]{2}{*}{$k_{\text {att } 1}\left(\mathrm{~h}^{-1}\right)$} & 1.18 & $9.03 \times 10^{-1}$ & $7.59 \times 10^{-1}$ & $7.4 \times 10^{-1}$ \\
\hline & $\left(4.33 \times 10^{-2}\right)$ & $\left(1.03 \times 10^{-1}\right)$ & $\left(3.05 \times 10^{-2}\right)$ & $\left(2.91 \times 10^{-2}\right)$ \\
\hline \multirow[t]{2}{*}{$k_{\operatorname{det} 1}\left(\mathrm{~h}^{-1}\right)$} & $3.22 \times 10^{-2}$ & $5.62 \times 10^{-5}$ & $4.68 \times 10^{-4}$ & $2.02 \times 10^{-4}$ \\
\hline & $\left(6.58 \times 10^{-3}\right)$ & $\left(5.71 \times 10^{-3}\right)$ & $\left(4.71 \times 10^{-5}\right)$ & $\left(2.06 \times 10^{-4}\right)$ \\
\hline \multirow[t]{2}{*}{$k_{\text {att2 }}\left(\mathrm{h}^{-1}\right)$} & - & $4.19 \times 10^{-1}$ & - & $3.32 \times 10^{-2}$ \\
\hline & & $\left(1.36 \times 10^{-1}\right)$ & & $\left(2.11 \times 10^{-2}\right)$ \\
\hline \multirow[t]{2}{*}{$k_{\operatorname{det} 2}\left(\mathrm{~h}^{-1}\right)$} & - & $4.17 \times 10^{-1}$ & - & $7.1 \times 10^{-3}$ \\
\hline & & $\left(3.67 \times 10^{-1}\right)$ & & $\left(5.79 \times 10^{-2}\right)$ \\
\hline \multirow{2}{*}{$\mu_{S}\left(\mathrm{~h}^{-1}\right)$} & $1.86 \times 10^{-1}$ & $1.89 \times 10^{-1}$ & $1.57 \times 10^{-5}$ & $1.09 \times 10^{-5}$ \\
\hline & $\left(1.14 \times 10^{-2}\right)$ & $\left(1.11 \times 10^{-2}\right)$ & $\left(1.21 \times 10^{-7}\right)$ & $\left(1.22 \times 10^{-7}\right)$ \\
\hline$R^{2}$ & 0.92 & 0.93 & 0.98 & 0.99 \\
\hline
\end{tabular}

Table 4. Pseudomonas fluorescens transport modeling goodness of fit (E).

\begin{tabular}{lccc}
\hline Model & Estimated & Column I & Column II \\
\hline One-site & BTCs & 0.90 & 0.94 \\
& Profile & 0.93 & 0.89 \\
Two-site & BTCs & 0.92 & 0.95 \\
& Profile & 0.94 & 0.90 \\
\hline
\end{tabular}

Table 5. Experimental and modeled mass balances for bacteria in the column outflow and retained in the columns.

\begin{tabular}{lcccccc}
\hline \multirow{2}{*}{ Soil Column } & \multicolumn{2}{c}{ Experimental } & \multicolumn{2}{c}{ One-Site Modeled } & \multicolumn{2}{c}{ Two-Site Modeled } \\
\cline { 2 - 7 } & Outflow $\%^{*}$ & Retained $^{* *} \%$ & Outflow\% & Retained $\%$ & Outflow\% & Retained\% \\
\hline I & 15.2 & 70.2 & 15.6 & 70.9 & 15.4 & 72.0 \\
II & 14.1 & 69.7 & 19.2 & 63.4 & 18.9 & 63.9 \\
\hline
\end{tabular}

"The percentage of bacteria mass in the column outflow.

${ }^{* *}$ The percentage of bacteria mass retained by processes such as attachment and straining.

\section{Bacteria distribution in the soil column}

The observed and simulated final spatial distributions of bacteria retained in the columns are illustrated in Fig. 3. The retention profile are plotted as normalized concentration (number of bacteria recovered in the soil, $\mathrm{N}_{\mathrm{t}}$, divided by the total number of bacteria injected into the column, $\mathrm{N}_{\mathrm{i}}$ ) per gram of dry soil as a function of distance from the column inlet. Most of the cells were retained close to the soil column inlet, and the rate of deposition decreased with depth. These observations can be attributed to bacteria straining. Some researchers have recognized straining as a potentially important mechanism for bacteria deposition (e.g. Bradford et al., 2004; Gargiulo et al., 2008; Pang et al., 2008). The calculated values of $E$ show that two-site model provides a better performance than one-site model to predict bacteria retention profile (Table 4). The obtained $E$ values of two-site model for the retention profile ranged from 0.87 to 0.94 .

Bacteria retention in saturated soil occurs by attachment and straining mechanisms. In many experiments it has been observed that attachment is an important mechanism influencing bacterial retention in porous media. The straining mechanism involves the physical blocking of movement through pores smaller than the bacteria (Stevik et al., 2004). Straining occurs when the ratio of the colloid to medium grain diameter, $D_{\mathrm{p}} / d$, is $>0.5 \%$ (Bradford et al., 2004), and will be significant when the ratio is $>8 \%$ (McDowell-Boyer et al., 1986). The criteria for straining were developed from uniform porous media grain sizes and these criteria do not consider the effect of soil aggre- gates and macropores (Pang et al., 2008). The current knowledge of straining processes is still incomplete and the effect of soil aggregation and macropores on straining is unknown. Therefore, in this research it was assumed that the attachment rate, $k_{\text {att }}$, also includes the effects of the straining.

\section{Removal of bacteria}

Removal rate of bacteria is the logarithmic reduction of bacteria concentration, $\log _{10}\left(C_{\max } / C_{0}\right)$. Knowledge of microbial removal rates by soil is essential for assessing the risk of groundwater contamination. Many factors affect bacterial removal rates in soil under saturated conditions. These include physical-chemical properties of soil, properties of bacteria, solution chemistry, inactivation, physical straining, heterogeneity and preferential flow paths (Pang, 2009).

The bacteria removal was $4.02-4.88 \operatorname{log~m}^{-1}$ in the calcareous soil (Table 6). The high reduction rate of bacteria can be attributed to attachment of bacteria to calcium carbonate that appears to be favorable attachment site for negatively charged bacteria. Pang et al. (2008) evaluated the ability of New Zealand soils to remove bacteria. They reported that microbial reduction is $100 \%$ in allophanic soil, 16 to $18 \log \mathrm{m}^{-1}$ in pumice soil and has been lowest in clayey gley soil $\left(0.1-2 \log \mathrm{m}^{-1}\right)$. For most other New Zealand soils, the reduction was 2 to $3 \log \mathrm{m}^{-1}$.

The high bacteria removal rates of allophanic and pumice soils have been attributed to net positive surface charge of these soils that is favorable attachment site for negatively charged bacteria. 


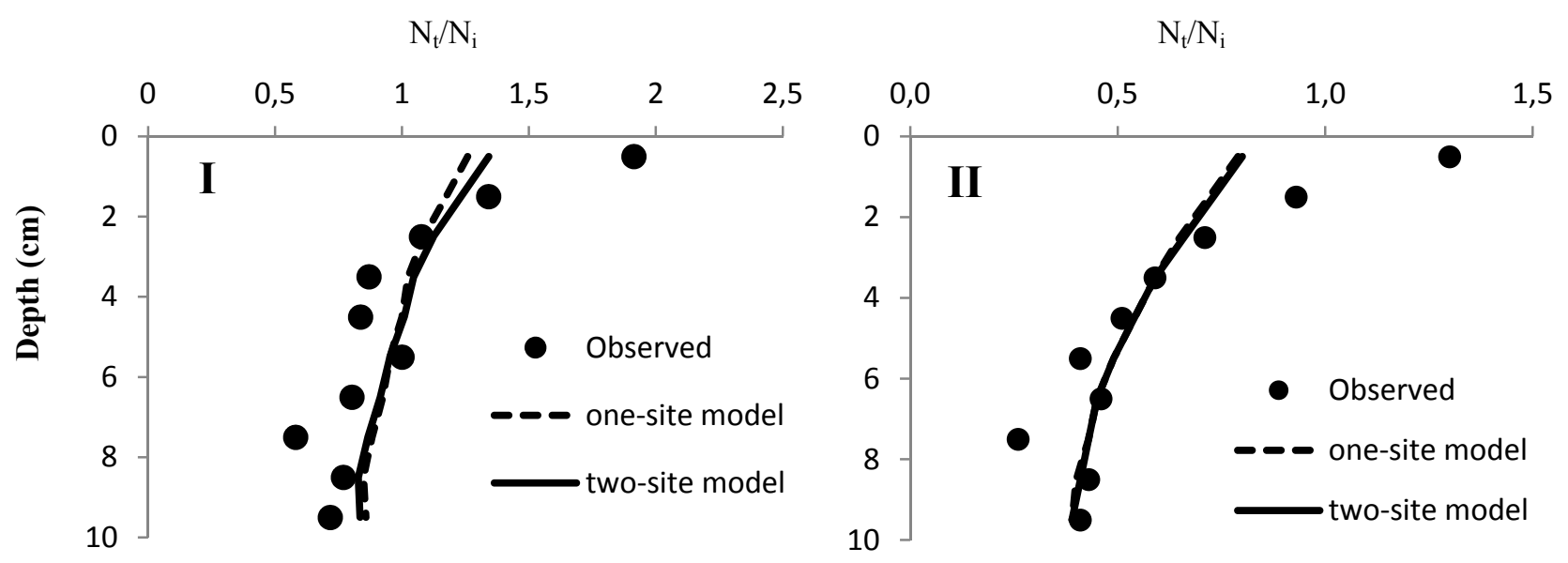

Fig. 3. Measured and fitted retention profiles for Pseudomonas fluorescens. The $N_{\mathrm{t}} / \mathrm{N}_{\mathrm{i}}$ denotes the number of bacteria found in each gram of soil $\left(\mathrm{N}_{\mathrm{t}}\right)$ divided by the total number of injected bacteria $\left(\mathrm{N}_{\mathrm{i}}\right)$. I and II are the columns numbers.

Table 6. Observed removal rate of bacteria in the soil columns.

\begin{tabular}{lcccccc}
\hline Soil Column & Column length $(\mathrm{m})$ & $\mathrm{C}_{\max }$ & $\mathrm{C}_{0}$ & $\mathrm{C}_{\max } / \mathrm{C}_{0}$ & $\log \left(\mathrm{C}_{\max } / \mathrm{C}_{0}\right)$ & Removal rate $^{\mathrm{a}}\left(\log \mathrm{m}^{-1}\right)$ \\
\hline $\mathrm{I}$ & 0.1 & $2.06 \times 10^{8}$ & $5.2 \times 10^{8}$ & 0.396 & 0.402 & 4.02 \\
$\mathrm{II}$ & 0.1 & $1.69 \times 10^{8}$ & $5.2 \times 10^{8}$ & 0.325 & 0.488 & 4.88 \\
\hline
\end{tabular}

${ }^{\mathrm{a}}$ Removal rate $=\log \left(C_{\max } / C_{\mathrm{o}}\right) / x \cdot x=$ column length.

\section{Mass balance}

The experimental and modeled mass balances for bacteria in the column outflow and that retained in the columns are given in Table 5. The total mass balance for the bacteria in the transport experiments ranged from 83.8 to $85.4 \%$. The results of experimental mass balance indicate that the total bacteria in the outflow were between 14.1 to $15.2 \%$, whereas more than $69.7 \%$ to $70.2 \%$ of bacteria were retained in the soil columns. It can be then concluded that based on the obtained mass balance data, the methods used to determine effluent and retention of bacteria have high level of accuracy. A wide range of recoveries from 14 to $86 \%$ has been reported in the literature (Darnault et al., 2004). This variability might have been caused by any one of the various steps involved in the cumbersome procedure used for the enumeration of the bacteria. In this research, direct microscopic count technique (Klauth et al., 2004) was used for bacterial enumeration in effluent samples. A major advantage of direct counts is the speed at which results are obtained. Direct count methods can be used to monitor changes in total bacterial numbers (living and dead or active and inactive bacterial cells).

\section{CONCLUSION}

Knowledge on processes and factors affecting transport and deposition of bacteria in soil is crucial for managing groundwater contamination as well as bioremediation practices. Most studies on transport of bacteria in agricultural soils have been conducted in qualitative manner, without attempting to model bacteria transport. In this research, bacteria transport in undisturbed calcareous soils under saturated conditions was quantitatively studied. Furthermore, the possibility of presence of more than one kinetic attachment site in agricultural soil was investigated. Experimental effluent and deposition data were described using one-site and two-site kinetic attachment-detachment models. Results revealed that the two-site kinetic model provides a reasonable description of both breakthrough curves and deposition profiles. Pseudomonas fluorescens cells can attach relatively fast to site 1 and detach quite slowly from the site, whereas both attachment to and detachment from the site 2 were fast. The detachment rate was only $2 \%$ of the attachment rate, indicating irreversible attachment of Pseudomonas fluorescens cells to positively charged calcium carbonate mineral. Agricultural soils are chemically heterogeneous porous media composed of different minerals with favorable and unfavorable attachment sites for negative charge bacteria adsorption. Results of this research show that soil mineralogy has significant influence on attachment rate and removal of bacteria. High attachment and removal rate of bacteria in the calcareous soils can mainly be attributed to the fact that at $\mathrm{pH} 7.4-7.52$, calcium carbonate is predominantly positively charged and thus favorable for attachment to negatively charged bacteria. The results also indicate that water velocity plays significant role in bacteria transport in soil, while calcium carbonate mineral had the greatest influence on attachment and detachment rates of bacteria (mass exchange).

\section{REFERENCES}

Bradford, S.A., Bettahar, M., Šimůnek, J., van Genuchten, M.Th., 2004. Straining and attachment of colloids in physically heterogeneous porous media. Vadose Zone J., 3, 384394.

Cey, E.E., Rudolph, D.L., Passmore, J., 2009. Influence of macroporosity on preferential solute and colloid transport in unsaturated field soils. J. Contam. Hydrol., 107, 1-2, 45-57.

Darnault, C.J.G., Steenhuis, T.S., Garnier, P., Kim, Y.J., Jenkins, M.B., Ghiorse, W.C., Baveye, P.C., Parlange, J.Y., 2004. Preferential flow and transport of Cryptosporidium parvum oocysts through the vadose zone: Experiments and modeling. Vadose Zone J., 3, 262-270. 
Drouinean, G., 1942. Dosage rapide du calcarire actif du sol:nouvellesdonnees sur la separation et la nature des fractionscalcaires. [Rapid determination of soil active limestone: New data on separation and nature of the limestone fractions]. Ann. Agron., 12, 441-450. (In French.)

Flynn, R., Hunkeler, D., Guerin, C., Burn, C., Rossi, P., Aragno, M., 2004. Geochemical influences on H40/1 bacteriophage inactivation in glaciofluvial sands. Environ. Geol., 45, 504-517.

Foppen, J.W.A., Schijven, J.F., 2005. Transport of E. coli in columns of geochemically heterogeneous sediment. Water Resour., 39, 3082-3088.

Foppen, J.W.A., Schijven, J.F., 2006. Evaluation of data from the literature on the transport and survival of Escherichia coli and thermotolerant coliforms in aquifers under saturated conditions.Water Res., 40, 401-426.

Foppen, J.W., Herwerden, M.V., Schijven, J., 2007. Measuring and modelling straining of Escherichia coli in saturated porous media. J. Contam. Hydrol., 93, 1-4, 236-254.

Foppen, J.W.A., Lutterodt, G., Röling, W.F.M., Uhlenbrook, S., 2010.Towards understanding inter-strain attachment variations of Escherichia coli during transport in saturated quartz sand. Water Res., 44, 1202-1212.

Foster, S.S.D., 2000. Groundwater resources at the turn of the millennium: taking stock and looking forward. In: Sillo et al. (Eds.): Groundwater: Past Achievements and Future Challenges. Balkema, Rotterdam, The Netherlands, pp. 27-33.

Gargiulo, G., Bradford, S.A., Simunek, J., Ustohal, P., Vereecken, H.,Klumpp, E., 2008. Bacteria Transport and Deposition under Unsaturated Flow Conditions: The Role of Water Content and Bacteria Surface Hydrophobicity. Vadose Zone J., 7, 2, 406-419.

Gilbert, R.G., Gerba, C.P., Rice, R.C., Bouwer, H., Wallis, C., Melnick, J.L., 1976. Appl. Environ. Microbiol., 32, 3, 333338.

Gould, W.D., Hagedorn, C., Bradinelli, T.R., Zablotwicz, R.M., 1985. New selective media for enumeration and recovery of fluorescent Pseudomonads from various habitats. Appl. Environ. Microbiol., 49, 1, 28-32.

Guber, A.K., Shelton, D.R., Pachepsky, Y.A., 2005. Transport and retention of manure borne coliforms in undisturbed soil columns.Vadose Zone J., 4, 828-837.

Hagedorn, C., Hansen, D.T., Simonson, G.H., 1978. Survival and movement of fecal indicator bacteria in soil under conditions of saturated flow. J. Environ. Qual., 7, 55-59.

Hendry, M.J., Lawrence, J.R., Maloszewski, P., 1999. Effects of velocity on the transport of two bacteria through saturated sand. Ground Water, 37, 1, 103-112.

Jiang, S., Pang, L., Buchan, G.D., Simůnek, J., Noonan, M.J., Close, M.E., 2010. Modeling water flow and bacterial transport in undisturbed lysimeters under irrigations of dairy shed effluent and water using HYDRUS-1D. Water Res., 44, 4, 1050-1061.

Johnson, W.P., Blue, K.A., Logan, B.E., Arnold, R.G., 1995. Modeling bacterial detachment during transport though porous media as a residence-time dependent process. Water Resour. Res., 31, 2649-2658.

Kadam, A.M.,Oza, G.H., Nemade, P.D., Shankar, H.S., 2008. Pathogen removal from municipal wastewater in constructed soil filter.Ecol. Eng., 33, 1, 37-44.

Klauth, P., Wilhelm, R., Klumpp, E., Poschen, L., Groeneweg, J., 2004. Enumeration of soil bacteria with the green fluorescent nucleic acid dye Sytox green in the presence of soil particles.Journal Microbiol. Methods, 59, 189-198.
Levy, J., Sun, K., Findlay, R.H., Farruggia, F.T., Porter, J., Mumy, K.L., Tomaras, J., Tomaras, A., 2007. Transport of Escherichia coli bacteria through laboratory columns of glacial-outwash sediments: Estimating model parameter values based on sediment characteristics. J. Contam. Hydrol., 89, 71-106.

McCaulou, D.R., Bales, R.C., McCarthy, J.F., 1994. Use of short-pule experiments to study bacteria transport through porous media. J. Contam. Hydrol., 15, 1-14.

McCaulou, D., Bales, R.C., Arnold, R.G., 1995. Effect of temperature-controlled motility on transport of bacteria and microspheres through saturated sediment. Water Resour. Res., $31,2,271-280$.

McDowell-Boyer, L.M., Hunt, J.R., Sitar, N., 1986.Particle transport through porous media. Water Resour. Res., 22, 1901-1921.

McMurry, S.W., Coyne, M.S., Perfect, E., 1998. Fecal coliform transport through intact soil blocks amended with poultry manure. J. Environ. Qual., 27, 86-92.

Mosaddeghi, M.R., Mahboubi, A.A., Zandsalimi, S., Unc, A., 2009. Influence of organic waste type and soil structure on the bacterial filtration rates in unsaturated intact soil columns. J. Environ. Manag., 90, 730-739.

Nash, J.E., Sutcliffe J.V., 1970. River flow forecasting through conceptual models part I - A discussion of principles, J. Hydrol., 10, 3, 282-290.

Nelson, R.E., 1982. Carbonate and gypsum. In: Page, A.L., Miller, R.H., Keeney, D.R. (Eds.): Methods of Soil Analysis, part II: Chemical and Microbiological Properties, 2nd ed. (SSSA Book Series No. 5), Madison, Wisc.: Soil Science Society of America and American Society of Agronomy, pp. 181-198.

Pachepsky, Y.A., Devin, B.A., Polyanskaya, L.M., Shelton, D.R., Shein, E.V., Guber, A.K., 2006. Limited entrapment model to simulate the breakthrough of Arthrobacter and Aquaspirillum in soil columns. Int. Agrophysics, 20, 207-218.

Pang, L., 2009. Microbial removal rates in subsurface media estimated from published studies of field experiments and large intact soil cores. J. Environ. Qual., 38,1531-1559.

Pang, L., McLeod, M., Aislabie, J., Šimůnek, J., Close, M., Hector, R., 2008. Modeling transport of microbes in ten undisturbed soils under effluent irrigation.Vadose Zone J., 7, 1, 97-111.

Pivetz, B.E., Kelsey, I.W., Steenhuis, T.S., Alexander, M., 1996.A procedure to calculate biodegradation during preferential flow through heterogeneous soil columns. Soil Sci. Soc. Am. J., 60, 381-388.

Schijven, J.F., Hassanizadeh, S.M., de Bruin, H.A.M., 2002. Two-site kinetic modeling of bacteriophages transport through columns of saturated dune sand. J. Contam. Hydrol., 57, 259-279.

Schijven, J., Šimůnek, J., 2002. Kinetic modeling of virus transport at field scale. J. Contam. Hydrol., 55, 1-2, 113-135.

Simunek, J., Sejna, M., Saito, H., Sakai, M., van Genuchten, M.Th., 2008. The HYDRUS-1D software package for simulating the one-dimensional movement of water, heat, and multiple solutes in variably-saturated media, Version 4.0x, Hydrus Series 3. Department of Environmental Sciences, University of California Riverside, Riverside, CA, USA.

Somasundaran P., Agar, G.E., 1967. The zero point of charge of calcite. J. Colloid Interface Sci., 24, 433-440.

Stevik, T.K., Ausland, A.K., Hanssen, J.F., 2004. Retention and removal of pathogenic bacteria in wastewater percolating through porous media: a review. Water Res., 38, 1355-1367. 
Syngouna, V.I., Chrysikopoulos, C.V., 2011. Transport of biocolloids in water saturated columns packed with sand: Effect of grain size and pore water velocity. J. Contam. Hydrol., $126,301-314$

Toride, N., Leij, F.J., van Genuchten, M.Th., 1999. The CXTFIT Code for Estimating Transport Parameters from Laboratory or Field Tracer Experiments Version 2.1.Research Report, vol. 137.U.S. Salinity Laboratory, Riverside, CA.

Tufenkji, N., 2007. Modeling microbial transport in porous media: Traditional approaches and recent developments. Advances in Water Res., 30, 1455-1469.

Tufenkji, N., Elimelech, M., 2004. Correlation equation for predicting single-collector efficiency in physicochemical filtration in saturated porous media. Environ. Sci. Technol., 38, 529-536.
Unc, A., Goss, M.J., 2003. Movement of faecal bacteria through the vadose zone. Water Air Soil Pollut., 149, 1-4, 327-337.

Vanderborght, J., Vereecken, H., 2007. Review of dispersivity length for transport modeling in soils. Vadose Zone J., 6, 1, 29-52.

van Elsas, J.D., Trevors, J.T., van Overbeek, L.S., 1991. Influence of soil properties on the vertical movement of genetically-marked Pseudomonas fluorescens through large soil microcosms. Biol. Fert. Soils, 10, 249-255.

Wang, Y., Bradford, S.A., Simunek, J., 2013.Transport and fate of microorganisms in soils with preferential flow under different solution chemistry conditions.Water Resour. Res., 49, $1-13$.

Received 30 July 2014 Accepted 3 February 2015 